\title{
PERFORMANCE EVALUATION OF FRICTION DAMPERS UNDER SEISMIC LOADS
}

\author{
Adithya G. S. ${ }^{1}$, H. Narendra ${ }^{2}$ \\ ${ }^{\text {I}}$ PG Student, Department of Civil Engineering, M. S. Ramaiah Institute of Technology, Bangalore, Karnataka, India- \\ 560054 \\ ${ }^{2}$ Faculty in Civil Engineering, Department of Civil Engineering, M. S. Ramaiah Institute of Technology, Bangalore, \\ Karnataka, India - 560054
}

\begin{abstract}
Several structural control techniques such as passive, active, semi active and hybrid control techniques are gaining importance in earthquake resistant design of structures. Friction damper is a passive type energy dissipating device, which dissipates the seismic energy by virtue of the solid friction developed between the two sliding surfaces. Friction dampers get activated at their slip load and starts dissipating energy. The maximum energy dissipation and least response of the structure occur at optimal slip load of friction dampers. In the present study, the optimal slip load of the friction dampers provided in a nine storey reinforced concrete frame model was evaluated analytically using nonlinear time history analysis. Then the effect of friction dampers on the displacements and forces in the structure was evaluated. Acceleration time histories of El Centro ground motion ( $N$-S component) and Indian seismic zone IV were used for the analysis. The analyses were carried out using SAP2000 computer package. The results confirmed that a good reduction in the displacements and forces is possible with the addition of friction dampers and hence it can be used as an alternative for the conventional ductility based design methods.
\end{abstract}

Keywords: Friction Damper, Nonlinear Time History Analysis, Optimal Slip Load, Energy Dissipation

\section{INTRODUCTION}

Earthquake is one among the most disastrous natural phenomenon known to the mankind, which induces huge amount of lateral loads in the structures. If the structures are not designed properly to resist these lateral loads, the structures will collapse, which leads to loss of life, financial losses and social sufferings. The conventional ductility based design methods have been used over the past decades for earthquake resistant design of structures in India, which have several drawbacks, mainly inadequate damage control. Because of these drawbacks, several structural control techniques have been developed over the years, in which the forces induced on the primary structure will be reduced by some other means and hence achieving better damage control. These structural controls may be of passive, active, hybrid or semi active control type. However the use of these structural control techniques is very much limited in India. In the present study, an attempt has been made to include friction dampers, a passive type energy dissipater, in a $\mathrm{G}+8$ storey reinforced concrete frame model situated in seismic zone IV of India and its effects on forces and displacements of the frame was evaluated analytically.

\section{FRICTION DAMPERS}

\subsection{Construction}

Friction damper is a passive type energy dissipating device, which dissipates the seismic energy by virtue of the solid friction developed between two sliding surfaces. This type of a device was pioneered by Pall in 1979 and many other damper models were tested experimentally and some of them were used in structures across the world. The construction of the friction damper involves connecting a series of steel plates with high strength steel bolts. Suitable friction pads can be sandwiched between the steel plates or steel plates will be specially treated to have sufficient friction between them. Depending upon the type of the bracing system in which they will be installed, the construction of the friction damper slightly varies.

\subsection{Working}

When the force acting on the friction damper reaches a predetermined value, the sliding surfaces starts slipping, thus dissipates the seismic energy. The slipping should starts before any of the main structural elements starts yielding. The predetermined load, at which the slipping occurs and damper starts dissipating the seismic energy, is called as slip load of the friction damper. The energy dissipating capacity of the friction damper depends on its slip load and hence the response of the structural system also depends on the slip load of the damper. For a friction damper installed in a structural system, there exists an optimal slip load, which corresponds to the least response of the structure. The energy dissipated by the friction dampers is also the maximum at their optimal slip load. Normally $10-15 \%$ variation in the optimal slip load does affect the response of the structure much and many of the previous studies confirms the same. 


\subsection{Modeling}

The behavior of the friction damper under the action of seismic loads is nonlinear and hence nonlinear time history analysis is required for the analysis of friction damped structures. The hysteresis loop of the friction dampers is large, rectangular and nearly stable which indicates higher energy dissipating capacity. As it similar to the rectangular loop of a perfectly elasto plastic material, the slip load of the friction damped can be treated as a fictitious yield force. Hence friction damper provided in an elastic brace can be modeled as a damped brace yielding at the slip load of the friction damper.

In the present study, the performance of the friction damper provided in a $\mathrm{G}+8$ storey reinforced concrete frame building was evaluated analytically using SAP2000 computer package. The friction dampers were provided in the single diagonal steel bracings. Assuming the building to be situated at Indian seismic zone IV, the optimal slip load was determined first. Then the response of both bare frame and friction damped frame was found out and compared with each other. The average reduction in both the displacements and forces was estimated. Later the performance of the friction dampers was also evaluated under El Centro ground motion (N-S component).

\section{DESCRIPTION OF THE ANALYTICAL}

\section{MODEL}

For the purpose of analyses, a G+8 storey reinforced concrete space frame model, made up of M30 concrete and Fe 500 steel was considered. The bay width was taken as $5 \mathrm{~m}$ with 5 bays in both directions and hence the total width of the building was $25 \mathrm{~m}$ in both the directions. The storey height was taken as $3 \mathrm{~m}$ with a plinth beam at a height of $1.5 \mathrm{~m}$, resulting in total height of $28.5 \mathrm{~m}$. Supports were assumed to be fixed and the soil structure interaction effects were neglected. Beam and column sizes were $230 * 450 \mathrm{~mm}$ and $500 * 500 \mathrm{~mm}$ respectively. $230 \mathrm{~mm}$ thick walls, $0.9 \mathrm{~m}$ height parapet walls, $175 \mathrm{~mm}$ thick slab, $1.5 \mathrm{kN} / \mathrm{m}^{2}$ finishes load, $4 \mathrm{kN} / \mathrm{m}^{2}$ live load on floors and $1.5 \mathrm{kN} / \mathrm{m}^{2}$ live load on roof were considered. A live load reduction factor of 0.5 for all floors and 0 for the roof was considered in the earthquake analysis as per IS 1893:2002. To account for the material damping, a modal damping of $5 \%$ of the critical was considered. In order to account for the geometrical nonlinearity effects, $\mathrm{P}-\Delta$ effects were included. The safety of the frame was initially checked against the load combination 1.5(DL+LL). Acceleration time histories of the El Centro ground motion (N-S component) and Indian seismic zone IV (specified by IS 1893:2002) were used in the nonlinear time history analysis.

In order to model the friction damper analytically, plastic (Wen) element was used in SAP2000. The bracing and the friction damper is together modeled as a damped brace having yield strength equal to the slip load of the friction damper. Only one active degrees of freedom U1 was specified for the friction damper as it is active only in its local axial direction. A yielding exponent of 10 indicating sharp transition from linear to nonlinear phase and a post yield stiffness ratio of 0.0001 indicating rectangular hysteresis loop, as suggested by Pall were used to describe the damper properties. The slip load of the friction damper is specified in terms of the yield strength, which is the primary variable and have more impact on the response of the frame. The effective stiffness was calculated corresponding to the bracing used, by assuming a bracing with strength slightly higher than the slip load of the friction damper.

\section{DETERMINATION OF THE OPTIMAL SLIP}

\section{LOAD}

The very much important step in the analysis and design of friction damped structures is to determine the optimal slip load of the friction dampers. In the present study, friction dampers were provided in the central bay along the periphery of frame and in the second and fourth bay in the interior of the frame, in both the directions and in each storey. Hence a total of 180 friction dampers were provided in the frame, with 90 dampers in each direction. However, in a practical building, the available locations for the placement of the friction dampers has to be find out first and it is required to provide them in both the directions to resist the seismic forces efficiently. In the present study uniform slip load was maintained along the height of the building, however it is possible to vary the slip load along the height to optimize the response and also the cost of the friction dampers. The optimal slip load of the friction damper corresponds to the least response of the structure and also the energy dissipated by the friction damper will be the maximum at their optimal slip load. Hence at optimal slip load, the difference between the input energy and damper dissipated energy will be the minimum. There are several criteria to select the optimal slip load for a particular structure. In the present study, the safety of the structure, maximum displacement of the roof, maximum base shear, percentage of input energy dissipated by the friction dampers and the maximum column axial loads due to earthquake were considered as the criteria to select the optimal slip load. These response quantities were first obtained for the bare frame using the nonlinear time history analysis. The friction damper element is then introduced and a series of nonlinear time history analyses were carried for various slip loads and above mentioned response quantities were obtained for each slip load. The optimal slip load is then selected as $350 \mathrm{kN}$ for the Indian seismic zone IV, at which all the elements are within their stress capacity, with minimum response and higher energy dissipation by the friction dampers. Even though if one or two response quantities are minimum at a particular slip load, but some of the members are exceeding their stress capacity, it should not be selected as an optimal slip load, as safety of the structure should always be the primary criteria. The detailed results obtained by the nonlinear time history analysis to determine the optimal slip load of the friction damper for the Indian seismic zone IV were given in Table -1 . 


\section{RESULTS AND DISCUSSIONS}

Once the optimal slip load of the friction damper was obtained, the response quantities were found out for both the bare frame and the friction damped frame and the results were compared. The response quantities considered in the present study includes, maximum storey displacements, inter storey drifts, maximum storey accelerations, maximum storey shear, maximum base shear, maximum beam moments at each storey level due to earthquake and maximum column axial loads and maximum column moments due to earthquake at each storey level. The optimal slip load was obtained by using Indian seismic zone IV time history and for the same optimal slip load the performance under the El Centro ground motion was evaluated. As the frame was symmetric in both the directions, the response quantities were also same in both the directions.

Table 1: Determination of the optimal slip load of the friction damper for seismic zone IV

\begin{tabular}{|c|c|c|c|c|c|c|c|}
\hline $\begin{array}{l}\text { Slip Load } \\
\text { of the } \\
\text { Friction } \\
\text { Damper in } \\
\mathrm{kN}\end{array}$ & $\begin{array}{l}\text { Total } \\
\text { Input } \\
\text { Energy } \\
\text { in } \mathrm{kN}-\mathrm{m}\end{array}$ & $\begin{array}{l}\text { Total } \\
\text { Energy } \\
\text { Dissipaed by } \\
\text { the Dampers } \\
\text { in kN-m }\end{array}$ & $\begin{array}{l}\text { Percentage of } \\
\text { Total Input } \\
\text { Energy } \\
\text { Dissipated by } \\
\text { the Dampers } \\
(\%)\end{array}$ & $\begin{array}{l}\text { Maximu } \\
\mathrm{m} \text { Base } \\
\text { Shear in } \\
\mathrm{kN}\end{array}$ & $\begin{array}{l}\text { Maximum } \\
\text { Displacement } \\
\text { of the Top } \\
\text { Storey in } \mathrm{mm}\end{array}$ & $\begin{array}{l}\text { Maximum } \\
\text { Axial Force in } \\
\text { the Members } \\
\text { in } \mathrm{kN}^{*}\end{array}$ & $\begin{array}{l}\text { No of } \\
\text { Members } \\
\text { Failed }\end{array}$ \\
\hline 0 & 6725 & 0 & 0.00 & 16120 & 192.1 & 2179 & 56 \\
\hline 50 & 7569 & 3096 & 40.90 & 14120 & 168.7 & 1915 & 18 \\
\hline 100 & 8384 & 4805 & 57.31 & 14680 & 154.6 & 1756 & 24 \\
\hline 150 & 8971 & 5880 & 65.54 & 14400 & 144.5 & 1638 & 22 \\
\hline 200 & 9362 & 6512 & 69.56 & 13770 & 135.4 & 1533 & 12 \\
\hline 250 & 9545 & 6811 & 71.36 & 12930 & 124.6 & 1409 & 2 \\
\hline 300 & 9788 & 7035 & 71.87 & 12410 & 118.8 & 1343 & 0 \\
\hline 350 & 10100 & 7254 & 71.82 & 11780 & 118.5 & 1337 & 0 \\
\hline 400 & 10420 & 7440 & 71.40 & 11620 & 119.2 & 1344 & 0 \\
\hline 450 & 10720 & 7588 & 70.78 & 11890 & 119.9 & 1352 & 0 \\
\hline 500 & 11010 & 7703 & 69.96 & 12070 & 120.5 & 1357 & 0 \\
\hline 550 & 11270 & 7780 & 69.03 & 12160 & 120.7 & 1359 & 0 \\
\hline 600 & 11500 & 7813 & 67.94 & 12120 & 120.2 & 1353 & 0 \\
\hline 650 & 11690 & 7802 & 66.74 & 12000 & 119.0 & 1340 & 0 \\
\hline
\end{tabular}

The maximum displacements for the frame at each storey level for both the bare frame and damped frame under zone IV input were given in Table -2 . The percentage reduction in the maximum displacement at each storey level and also the average reduction in the displacements were estimated. In the same way, the reductions in all the response quantities were determined. The variation of the maximum displacement, inter storey drifts, maximum beam moments and maximum column axial loads for the bare and damped frames, under both the zone IV and El Centro ground motion were shown in Figure -1 to Figure -8 respectively. The average reductions in each of the response quantities for both the earthquake inputs were estimated and are given in Table- 3 .

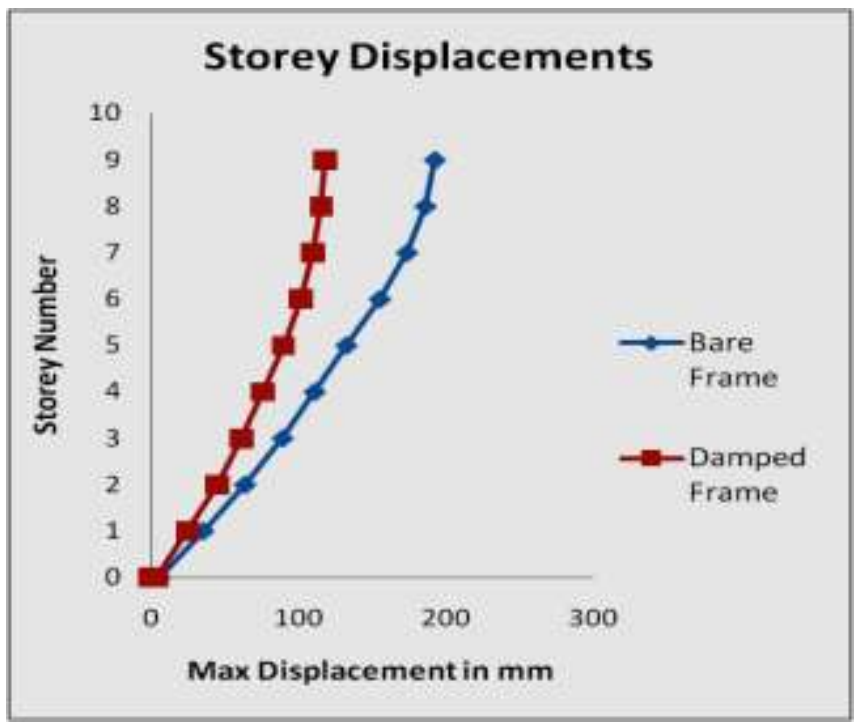

Fig 1: Variation of maximum displacement with and without dampers for zone IV input 
Table 2: Maximum storey displacements for the frame with and without damper for zone IV input

\begin{tabular}{|c|c|c|c|c|}
\hline $\begin{array}{l}\text { Floor } \\
\text { Number }\end{array}$ & $\begin{array}{l}\text { Maximum } \\
\text { Displacement for Bare } \\
\text { Frame in } \mathrm{mm}\end{array}$ & $\begin{array}{l}\text { Maximum Displacement } \\
\text { for Damped Frame in } \\
\mathrm{mm}\end{array}$ & $\begin{array}{l}\text { Reduction in } \\
\text { Displacement in } \mathrm{mm}\end{array}$ & $\begin{array}{l}\text { Percentage Reduction in } \\
\text { Displacement }(\%)\end{array}$ \\
\hline 9 & 192.1 & 118.5 & 73.6 & 38.31 \\
\hline 8 & 185.7 & 115.7 & 70.0 & 37.70 \\
\hline 7 & 173.3 & 110.1 & 63.2 & 36.47 \\
\hline 6 & 155.0 & 101.6 & 53.4 & 34.45 \\
\hline 5 & 132.5 & 90.2 & 42.3 & 31.92 \\
\hline 4 & 111.0 & 76.3 & 34.7 & 31.23 \\
\hline 3 & 89.4 & 61.8 & 27.6 & 30.87 \\
\hline 2 & 64.1 & 45.1 & 19.0 & 29.63 \\
\hline 1 & 35.9 & 25.2 & 10.7 & 29.73 \\
\hline Plinth & 6.3 & 4.4 & 1.9 & 29.71 \\
\hline Ground & 0.0 & 0.0 & 0.0 & \\
\hline & & \multicolumn{2}{|c|}{ Avg Reduction in Displacement $(\%)=$} & 33.00 \\
\hline
\end{tabular}

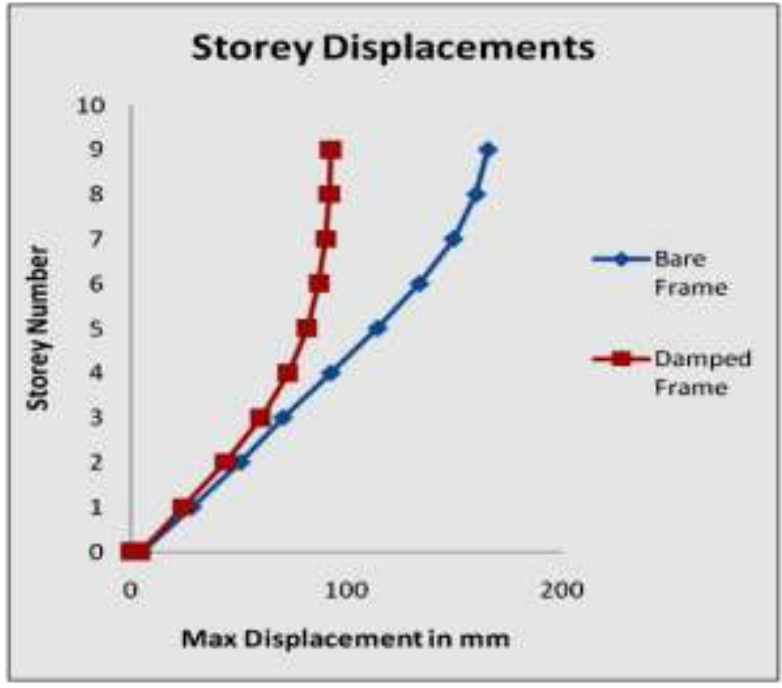

Fig 2: Variation of maximum displacement with and without dampers for El Centro input

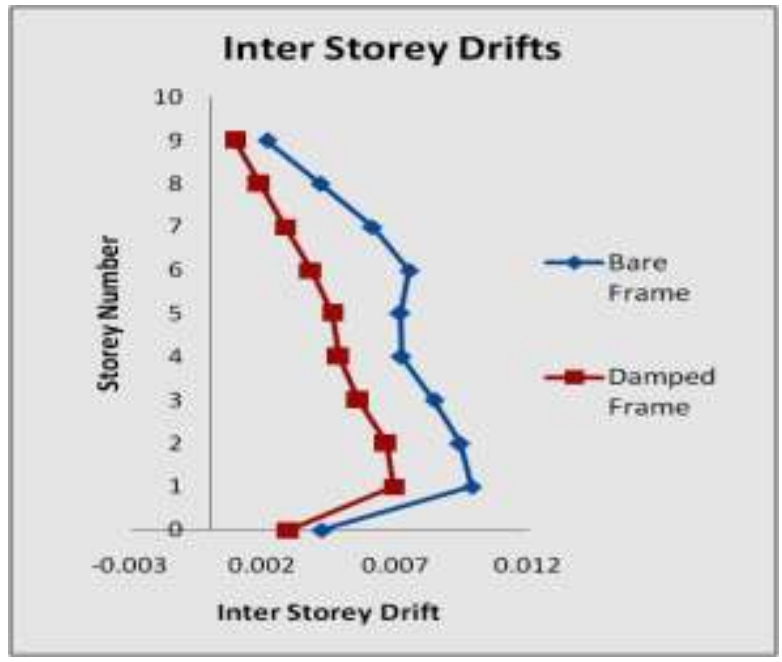

Fig 3: Variation of inter storey drifts with and without dampers for zone IV input

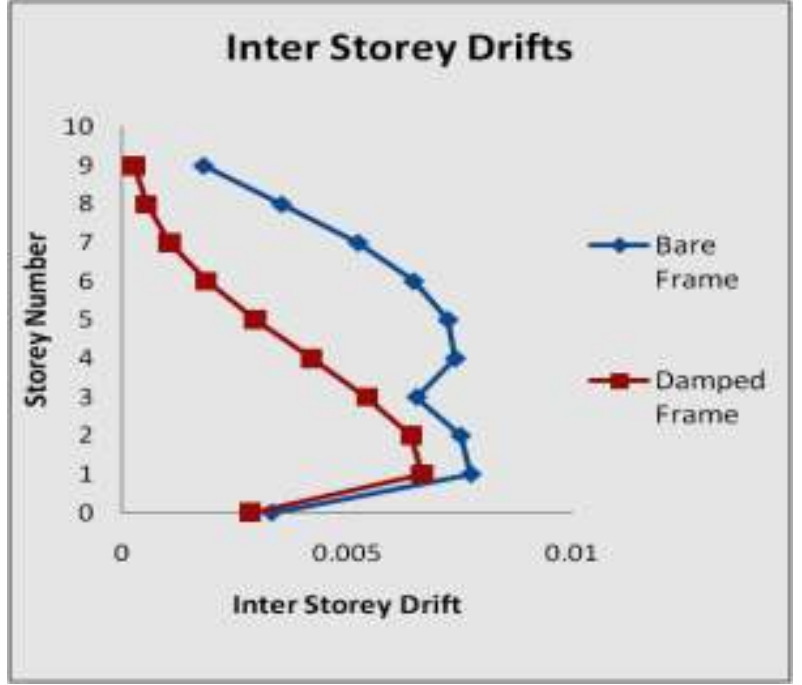

Fig 4: Variation of inter storey drifts with and without dampers for El Centro input

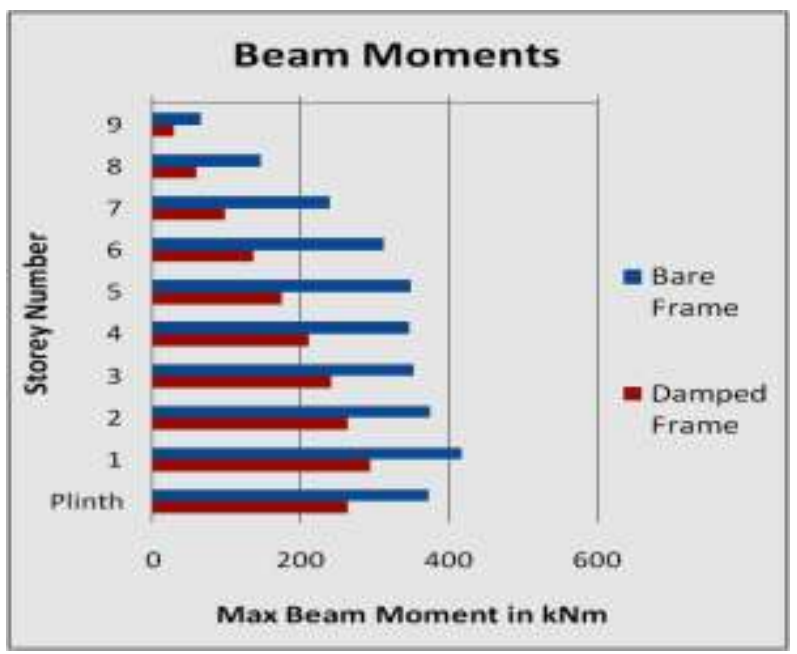

Fig 5: Variation of maximum beam moments with and without dampers for zone IV input 
Table 3: Average reduction in the response quantities

\begin{tabular}{|l|l|l|l|l|l|l|l|l|}
\hline \multirow{2}{*}{$\begin{array}{l}\text { Earthquake } \\
\text { Input }\end{array}$} & \multicolumn{2}{|l|}{ Average Reduction (\%) in } \\
\cline { 2 - 9 } & $\begin{array}{l}\text { Base } \\
\text { Shear }\end{array}$ & Displacement & $\begin{array}{l}\text { Acceleratio } \\
\mathrm{n}\end{array}$ & $\begin{array}{l}\text { Storey } \\
\text { Drifts }\end{array}$ & $\begin{array}{l}\text { Storey } \\
\text { Shear }\end{array}$ & $\begin{array}{l}\text { Column } \\
\text { Axial } \\
\text { Loads }\end{array}$ & $\begin{array}{l}\text { Column } \\
\text { Moments }\end{array}$ & $\begin{array}{l}\text { Beam } \\
\text { Moments }\end{array}$ \\
\hline Zone 4 & 26.92 & 33.00 & 23.58 & 40.52 & 13.39 & 55.12 & 46.32 & 44.06 \\
\hline El Centro NS & 12.90 & 26.87 & 26.10 & 48.36 & 15.02 & 62.75 & 46.53 & 46.36 \\
\hline
\end{tabular}

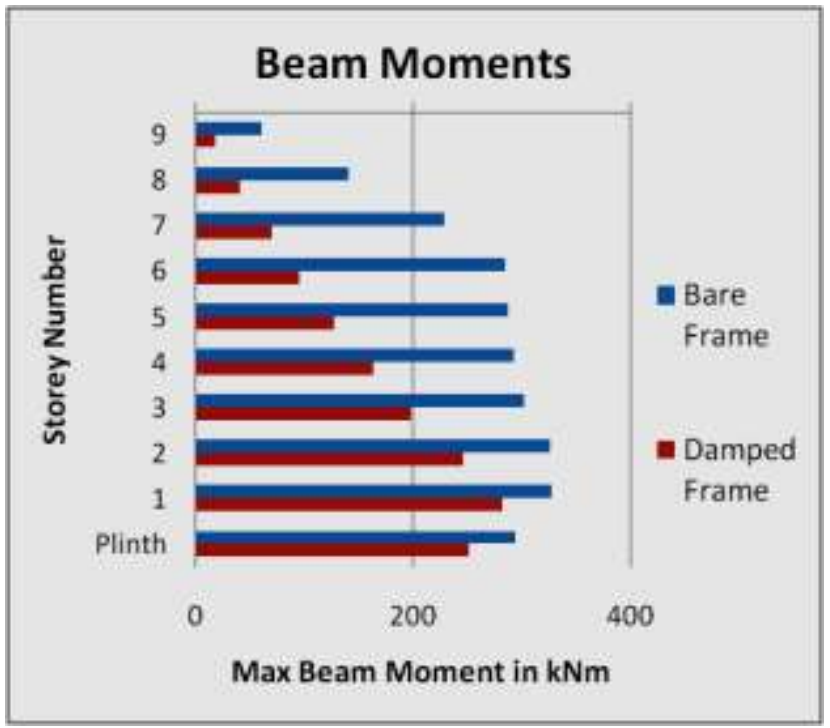

Fig 6: Variation of maximum beam moments with and without dampers for El Centro input

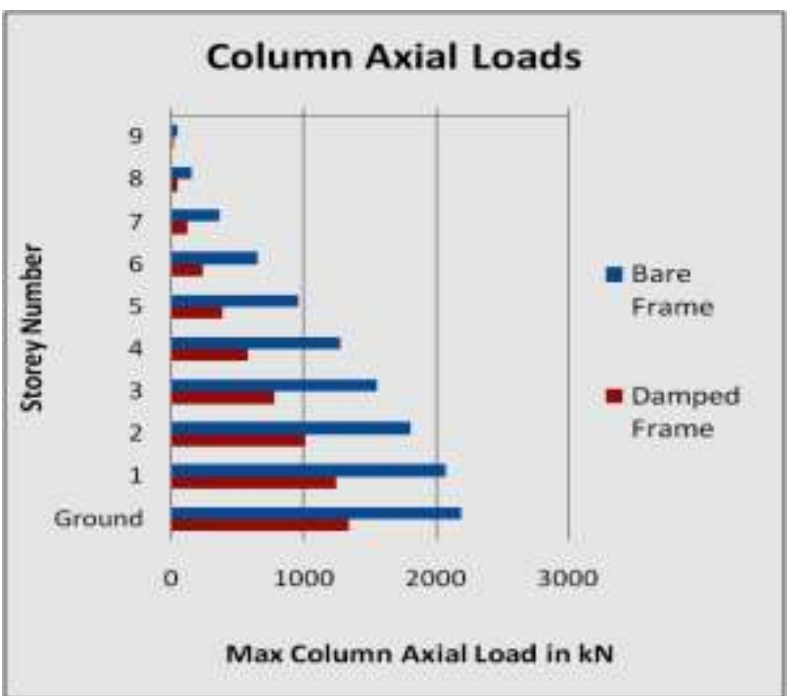

Fig 7: Variation of column axial loads with and without dampers for zone IV input

Time histories of the input energy, energy dissipated by the friction dampers at optimal slip load and the material damping energy for the zone IV input signal are shown in Figure - 9. It is evident that the friction dampers dissipates a major portion of the seismic energy and hence reduces the energy input to the primary structure.

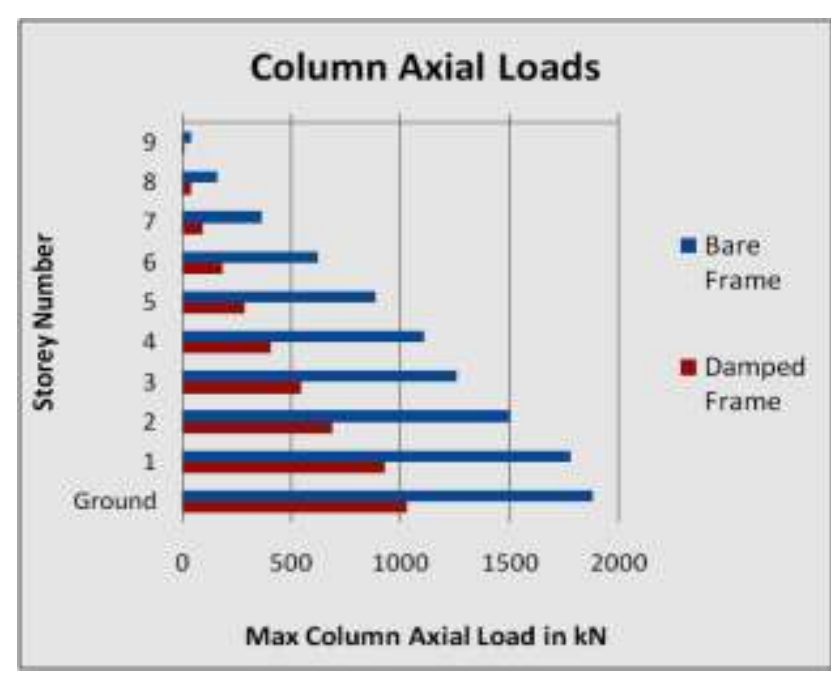

Fig 8: Variation of column axial loads with and without dampers for El Centro input

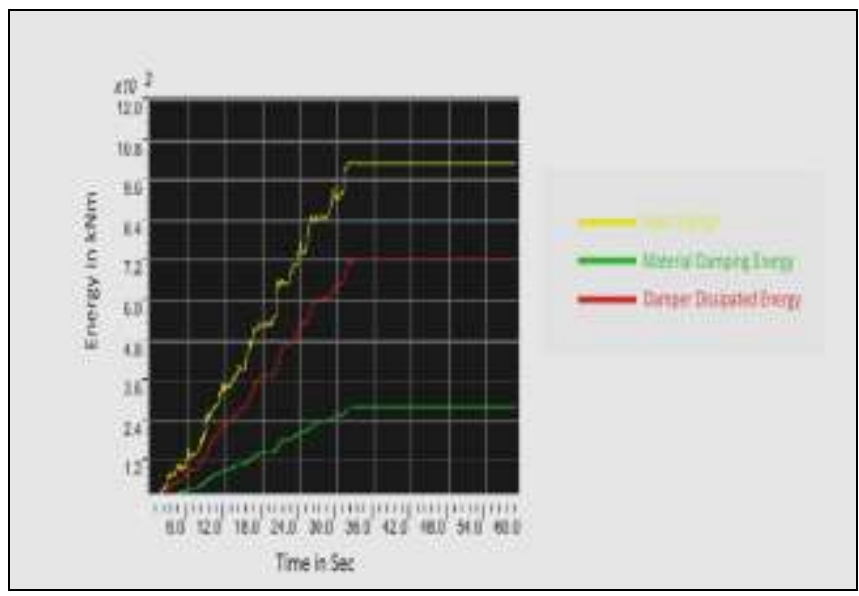

Fig 9: Time histories of input energy, material damping energy and damper dissipated energy for zone IV input

\section{CONCLUSION}

From the results of the nonlinear time history analysis on the frame with and without dampers the following conclusions are drawn.

- The friction dampers are able to dissipate a major portion of the seismic energy and hence help in safeguarding the building by reducing the energy input to the primary structure.

- The slip load of the friction damper is the primary variable in the analysis of friction damped structure and it controls the response of the damped frame. Hence it is possible to optimize the response of the structure by proper selection of optimal slip load. 
- The introduction of the friction dampers in the frame considerably reduced both the forces and displacements in the structure and hence the requirement of large sections to take care of earthquake forces is eliminated.

- It can also be concluded that the use of friction dampers can provide an alternative approach for the conventional ductility based design methods for the earthquake resistant design of structures.

\section{REFERENCES}

[1] Amiri JV and Nesheli PE (2013), Response Modification Factor of Chevron Braced Frame with Pall Friction Damper, International Journal of Engineering, Vol-26, No. 2, pp. 127-135

[2] Chandra R, Masand M, Nanda SK, Tripathi CP, Pall R and Pall AS (2000), Friction Dampers for Seismic Control of La Gardenia Towers South City, Gurgaon, India, Twelfth World Conference on Earthquake Engineering, Auckland, New Zealand.

[3] Indian standard criteria for earthquake resistant design of structures - General provisions and buildings, IS 1893 (Part - 1): 2002, Bureau of Indian Standards, New Delhi.

[4] Jafarzadeh K, Lotfollahi-Yaghin $M$ and Sabetahd R (2012), Evaluation of Pall Friction Damper performance in Near Fault Earthquakes by using of Nonlinear time history Analysis, World Applied Sciences Journal 20 (2) :264-270

[5] Mahmoudi M, Mirzaei A and Vosough S (2013), Evaluating Equivalent Damping and Response Modification Factor of Frames Equipped by Pall Friction Dampers, Journal of Rehabiltation in Civil Engineering 1-1, pp. 78-92.

[6] Mualla IH, Nielsen LO, Belev B, Liao WI, Loh CH and Agarawal A (2000), Numerical prediction of shaking table tests on a full scale friction damped structure, Twelfth European Conference on Earthquake Engineering, Auckland, New Zealand.

[7] Nikam SG, Wagholikar SK and Patil GR (2014), Seismic Energy Dissipation of a Building Using Friction Damper, International Journal of Innovative Technology and Exploring Engineering - vol-3, Issue10.

[8] Pall AS and Marsh C (1982), Response of Friction Damped Braced Frames, Journal of the Structural Division, Proceedings of the ASCE, CASCE, vol. 108, No. ST6.

[9] Pall AS and Pall R (1996), Friction dampers for seismic control of buildings - A Canadian Experience, Eleventh world conference on Earthquake Engineering, Mexico, Paper No. 497.

[10] Raut BR and Jangid RS (2013), Seismic analysis of benchmark building installed with friction dampers, The IES Journal Part A : Civil and Structural Engineering, 7:1, 20-37.

[11] Soong TT and Spencer BF (2002), Supplemental energy dissipation: state of the art and state of the practice, Journal of Engineering structures 24, pp. 243259. 